Article

\title{
Performance of Different Immobilized Lipases in the Syntheses of Short- and Long-Chain Carboxylic Acid Esters by Esterification Reactions in Organic Media
}

\author{
Lionete Nunes de Lima ${ }^{1}$, Adriano Aguiar Mendes ${ }^{2}$ (D), Roberto Fernandez-Lafuente ${ }^{3, *}$ (1), \\ Paulo Waldir Tardioli ${ }^{1, *(1)}$ and Raquel de Lima Camargo Giordano ${ }^{1}$ \\ 1 Graduate Program in Chemical Engineering, Department of Chemical Engineering, \\ Federal University of São Carlos, 13565-905 São Carlos, SP, Brazil; lionetenunes@yahoo.com.br (L.N.d.L.); \\ raquel@ufscar.br (R.d.L.C.G.) \\ 2 Institute of Chemistry, Federal University of Alfenas, 37130-001 Alfenas, MG, Brazil; \\ adriano.mendes@unifal-mg.edu.br \\ 3 Department of Biocatalysts, ICP-CSIC, Campus UAM-CSIC, 28049 Madrid, Spain \\ * Correspondence: rfl@icp.csic.es (R.F.-L.); pwtardioli@ufscar.br (P.W.T.); \\ Tel.: +34-91-595-4941 (R.F.-L.); +55-16-3351-9362 (P.W.T.)
}

Academic Editor: Derek J. McPhee

Received: 23 February 2018; Accepted: 24 March 2018; Published: 27 March 2018

\begin{abstract}
Short-chain alkyl esters and sugar esters are widely used in the food, pharmaceutical and cosmetic industries due to their flavor and emulsifying characteristics, respectively. Both compounds can be synthesized via biocatalysis using lipases. This work aims to compare the performance of commercial lipases covalently attached to dry acrylic beads functionalized with oxirane groups (lipases from Candida antarctica type B-IMMCALB-T2-350, Pseudomonas fluorescens-IMMAPF-T2-150, and Thermomyces lanuginosus-IMMTLL-T2-150) and a home-made biocatalyst (lipase from Pseudomonas fluorescens adsorbed onto silica coated with octyl groups, named PFL-octyl-silica) in the syntheses of short- and long-chain carboxylic acid esters. Esters with flavor properties were synthetized by esterification of acetic and butyl acids with several alcohols (e.g., ethanol, 1-butanol, 1-hexanol, and isoamyl alcohol), and sugar esters were synthetized by esterification of oleic and lauric acids with fructose and lactose. All biocatalysts showed similar performance in the syntheses of short-chain alkyl esters, with conversions ranging from 88.9 to $98.4 \%$. However, in the syntheses of sugar esters the performance of PFL-octyl-silica was almost always lower than the commercial IMMCALB-T2-350, whose conversion was up to $96 \%$ in the synthesis of fructose oleate. Both biocatalysts showed high operational stability in organic media, thus having great potential for biotransformations.
\end{abstract}

Keywords: immobilized lipases; esterification; flavor esters; sugar esters

\section{Introduction}

Many short-chain alkyl esters exhibit flavors similar to those of common fruits $[1,2]$. Consequently, they are widely used in pharmaceutical, cosmetics and food industries. Even though aromatic esters might be obtained from natural sources, an alternative to the extraction of these compounds is their chemical synthesis by esterification reactions. These can be catalyzed by inorganic catalysts or biocatalysts [3,4]. Inorganic catalysts require high temperatures, hence requiring high energy costs, and present low selectivity, making the downstream process complex [4]. When using biocatalysts, the reaction conditions are milder and the reactions are more selective [4,5]. In addition, esters 
synthesized through biocatalysis may be considered closed to "identical to natural" [4,6,7] and thus labeled as green products.

Another ester family of great interest is that composed by the sugar fatty acid esters, which are non-ionic surfactants [8]. These substances are biodegradable, with a varied variety of uses in many different economic sectors, e.g., the cosmetic, food, oral-care, detergent and pharmaceutical industries $[4,9,10]$.

The industrial synthesis of sugar fatty acid esters (e.g., long- or medium-chain fatty acids of glucose, fructose or sucrose) is carried out by transesterification of fatty acid methyl esters (more expensive than the fatty acids) using alkaline or metallic catalysts. The reaction requires high temperatures $\left(>100{ }^{\circ} \mathrm{C}\right)$ and the use of reduced pressure in order to remove the methanol released from the activated acyl donor to prevent competition with the hydroxyl groups of the carbohydrates [8]. In addition, the chemical catalysts are mostly alkaline and the reaction often uses dimethylformamide (DMF), pyridine or dimethylsulfoxide (DMSO) that are toxic solvents. This implies high energy costs, the production of undesired by-products and low selectivity [11-15]. Moreover, the most challenging features of this process are the control of the degree of esterification and the position of acylation $[8,16]$, and both are difficult to achieve using alkaline catalysis. Therefore, enzymatic synthesis of sugar esters might be a useful alternative, which is already used in industrial scale for some applications [4]. In these reactions, in order to dissolve the carbohydrate, the use of very polar solvents is required. The commonly used organic solvents, such as DMF or DMSO, are able to dissolve saccharides, but they usually have very negative effects for enzymes and are not compatible for many applications of carbohydrate-derived products $[7,17,18]$. Hence, the solvent must reconcile carbohydrate solubility and low polarity to reduce the damage of the enzyme. In addition, the solvent must not present reactive hydroxyl groups able to compete with the sugars, carboxylic groups or esters bonds, which could be substrates of the enzyme and reduce the product yield and/or produce side-products. In general, tertiary alcohols meet these requirements, as lipases do not recognize them as substrates [19-21]. Other examples of solvents that might be used in such reactions are ionic liquids [7,22-24]. Within the biocatalysts which can be used in the synthesis of esters, the most common ones are lipases $[3,4,14,18,25-35]$. Lipases can catalyze esterification reactions, provided that the reaction occurs at low water content [36]. Lipases present a peculiar catalytic mechanism, the so-called interfacial activation $[37,38]$. According to this mechanism, in homogenous aqueous media, the lipase molecules are in a conformational equilibrium between a closed form, with the active center inaccessible for the reaction media due to the presence of a polypeptide chain called lid that block it, and the open form, where the lid is displaced and exposes the lipase active center to the medium [39-41]. In the presence of any hydrophobic surface, e.g., a hydrophobic support, another open form of the lipase or a hydrophobic protein [40,42,43], the open form of the lipase becomes adsorbed via the hydrophobic area formed by the surrounding of the active center and the internal side of the lid, shifting the conformational equilibrium and fixing the open form of the lipase stabilized versus the surface of the support [44-46].

Esterification is a thermodynamically controlled process, where the yields are only defined by the thermodynamics of the process [21,47], the catalyst only defines the velocity and the possibility of the process [48]. To improve the yields, the thermodynamic equilibrium must be shifted. Reducing the water content (even eliminating the produced water) is the usual way to improve the yields. In these esterification reactions, the use of ultrasound irradiation to prevent the formation of water layers on the immobilized enzyme [49,50], the use of very hydrophobic supports (also to avoid the gathering of water in the enzyme surroundings) [51,52] and the use of molecular sieves to eliminate the produced water $[7,32,53,54]$, have all proven to be very useful to shift the equilibrium and prevent biocatalyst inactivation. In the case of sugars, the situation is more complex, as the catalyst may define the position or positions that are acylated, therefore the biocatalyst may also define in a certain sense the yields of the target product. The possibility of acyl migration must be considered, as this may produce the final modification of positions different to the ones modified by the enzyme $[51,55,56]$. 
In this work, lipase from Pseudomonas fluorescens (PFL), Candida antarctica type B (CALB) and Thermomyces lanuginosus (TLL) in one of their commercial immobilized forms (covalently attached to an acrylic resin functionalized with oxirane groups) were used as biocatalysts in the syntheses of esters with flavor and surfactant properties. These lipases, specially CALB, have been frequently employed in the synthesis of esters in nonaqueous medium $[4,7,8,10,57,58]$. PFL immobilized on silica particles coated with octyl groups (octyl-silica) was also used. Hydrophobically coated supports immobilize the lipases very efficiently and enable the one step immobilization, purification and stabilization of the open form of the lipase, due to the interfacial activation of the lipases on the hydrophobic surface of the support $[39,44,48]$. Among the several pre-existing supports, silica has been reported as a good choice for enzyme immobilization due to some properties, such as thermal and mechanical stabilities, high surface area, high resistance to organic solvents and microbial degradation and nontoxicity [59]. Biocatalysts prepared by immobilization of several lipases onto ocytl-silica has been successfully used in biotransformation reactions in organic media [26,28,59-61]. The preparation of octyl-silica and the immobilization of PFL on this support were previously reported by our group and evaluated in the synthesis of ethyl fatty acid esters [60] and fructose fatty acid ester [28]. In this new research effort, we intend to analyze if the immobilization protocol may affect the final properties of immobilized lipases in esterification reactions involving substrates as different as sugars, short alcohols and short or long chain carboxylic acids.

\section{Results and Discussion}

\subsection{Synthesis of Aroma Esters}

Table 1 shows the conversions observed in the syntheses of short-chain carboxylic acid esters by esterification catalyzed by home-made PFL-octyl-silica and commercial immobilized lipases at $37^{\circ} \mathrm{C}$ after $24 \mathrm{~h}$ of reaction. All biocatalysts showed excellent performance in the synthesis of flavor esters, yielding conversions ranging from 80.3 to $98.4 \%$ after $24 \mathrm{~h}$ reaction. Similar results have been reported for other reaction systems (reaction time, enzyme and organic solvent) [4]. PFL-octyl-silica, the home made preparation, offered yields over 95\% for all alcohols. IMMTLL-T2-150 offered the worst performance when hexanol was the substrate, only giving $80 \%$ after $24 \mathrm{~h}$, and just $90 \%$ when isoamyl alcohol and ethanol were used. IMMAPF-T2-150 only offered yields under $90 \%$ using ethanol, the higher yields were obtained using butanol (with both, acetic and butyric acid). IMMCALB-T2-350 gave the worst results using ethanol (just over 90\%). In an esterification, yields should be identical, thus the difference in yields should be related to some kinetic problem that can slow down the reaction rate in some instances. PFL-octyl-silica seems to be the most suitable biocatalyst for these esterifications among the assayed ones.

Table 1. Conversions of syntheses of short-chain carboxylic acid esters at $37^{\circ} \mathrm{C}$ for $24 \mathrm{~h}$, catalyzed by home-made PFL-octyl-silica and commercial immobilized lipases. Reactant concentrations: 0.1 M in heptane for acids and alcohols, and $200 \mathrm{U} / \mathrm{g}$ of acid (esterification activity) $20 \mathrm{~g} / \mathrm{L}$ molecular sieves for all biocatalysts.

\begin{tabular}{|c|c|c|c|c|c|c|c|}
\hline \multicolumn{4}{|c|}{ Reactants and Products } & \multicolumn{4}{|c|}{ Conversions (\%) by Biocatalyst } \\
\hline $\begin{array}{l}\text { Acyl } \\
\text { donor }\end{array}$ & Acyl acceptor & Ester & $\begin{array}{l}\text { FEMA flavor } \\
\text { profile }^{1}\end{array}$ & PFL-octyl-silica & IMMTLL-T2-150 & IMMAPF-T2-150 & IMMCALB-T2-350 \\
\hline Acetic acid & 1-butanol & Butyl acetate & $\begin{array}{l}\text { apple, banana, } \\
\text { pungent }\end{array}$ & $96.8 \pm 0.1$ & $97.0 \pm 0.0$ & $93.8 \pm 0.4$ & $96.8 \pm 0.1$ \\
\hline Acetic acid & 1-hexanol & Hexyl acetate & $\begin{array}{l}\text { apple, banana, } \\
\text { grass, herb, pear }\end{array}$ & $98.0 \pm 2.9$ & $80.3 \pm 1.5$ & $96.9 \pm 0.1$ & $97.5 \pm 3.5$ \\
\hline Acetic acid & $\begin{array}{l}\text { isoamyl } \\
\text { alcohol }\end{array}$ & Isoamyl acetate & $\begin{array}{l}\text { Apple, banana, } \\
\text { glue, pear }\end{array}$ & $96.9 \pm 0.2$ & $91.5 \pm 0.0$ & $93.7 \pm 0.2$ & $95.0 \pm 2.4$ \\
\hline $\begin{array}{c}\text { Butyric } \\
\text { acid }\end{array}$ & 1-butanol & Butyl butyrate & floral & $98.4 \pm 2.3$ & $93.5 \pm 0.0$ & $96.9 \pm 0.1$ & $96.6 \pm 0.1$ \\
\hline Acetic acid & ethanol & Ethyl acetate & $\begin{array}{c}\text { Aromatic, } \\
\text { brandy, grape }\end{array}$ & $96.7 \pm 0.1$ & $90.8 \pm 0.2$ & $88.9 \pm 1.9$ & $90.5 \pm 0.3$ \\
\hline
\end{tabular}

\footnotetext{
${ }^{1}$ Flavor \& Extract Manufactures Association (FEMA), available in https:/ / www.femaflavor.org/flavor-library.
} 


\subsection{Operational Stability of the Different Biocatalyst in the Synthesis of Butyl Butyrate}

The operational stabilities of all biocatalysts were evaluated in the syntheses of butyl butyrate at $37^{\circ} \mathrm{C}$ for reactions cycles of $24 \mathrm{~h}$ (Figure 1). All biocatalysts maintained maximum conversion after eight reaction cycles, except the commercial IMMAPF-T2-150, whose performance in the synthesis of butyl butyrate was greatly reduced to approximately $60 \%$ conversion after seven cycles. This contrasts with the very good behavior of PFL-octyl-silica, that suggests a great improvement on the enzyme performance upon immobilization on the hydrophobic support prepared in this work. This could be related to the lower adsorption of water, acids and alcohol in the enzyme environment $[51,55,62]$.

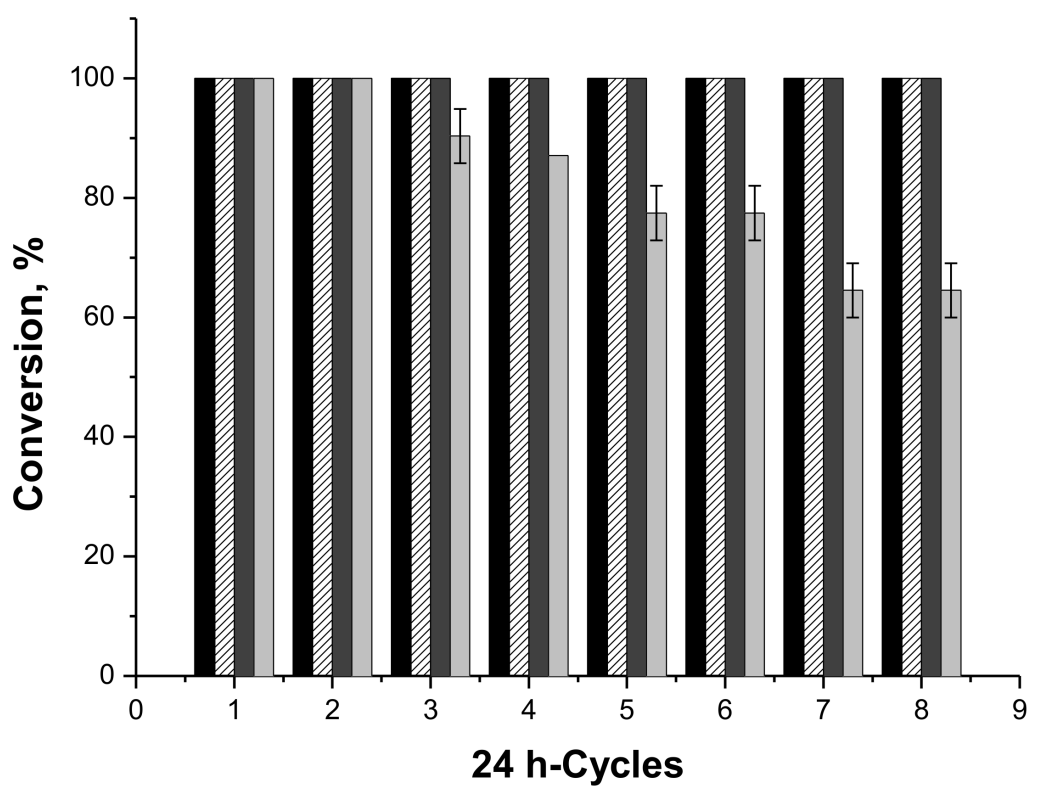

Figure 1. Reaction conversions as function of the number of cycles of butyl butyrate synthesis at $37^{\circ} \mathrm{C}$ for $24 \mathrm{~h}$ cycles, using $0.1 \mathrm{M}$ in heptane for acids and alcohols, and $200 \mathrm{U} / \mathrm{g}$ of acid (esterification activity) and $20 \mathrm{~g} / \mathrm{L}$ molecular sieves for all biocatalysts. IMMTLL-T2-150 (dark gray column), IMMAPF-T2-150 (gray column), IMMCALB-T2-350 (black column), PFL-octyl-silica (hatched column)-100\% was the conversions of the first reaction cycle. All assays were performed in duplicate and the standard deviations were very closed to zero, with only a few closed to $2 \%$.

\subsection{Reaction Course of Butyl Butyrate Synthesis by PFL-Octyl-Silica and IMMCALB-T2-350 Biocatalysts}

The home-made biocatalyst PFL-octyl-silica and the commercial IMMCALB-T2-350 were chosen to evaluate the reaction course in the conversion of butyl butyrate synthesis. In this set of experiments, the reaction progress was monitored by consumption of both, 1-butanol by gas chromatography and butyric acid by titration. Figure 2 (PFL-octyl-silica catalyzed synthesis) and Figure 3 (IMMCALB-T2-350 catalyzed synthesis) shows that over $90 \%$ conversion is achieved within only $2 \mathrm{~h}$ of reaction. Although both preparations were very active, IMMCALB-T2-350 was slightly more active in this reaction. Besides, it can be noticed that the conversion calculated from data of titration and gas chromatography agree reasonably well throughout the reaction. Thus, monitoring the reaction by acid titration (particularly when stoichiometric ratio is used) is a simpler and faster method to be used routinely. 


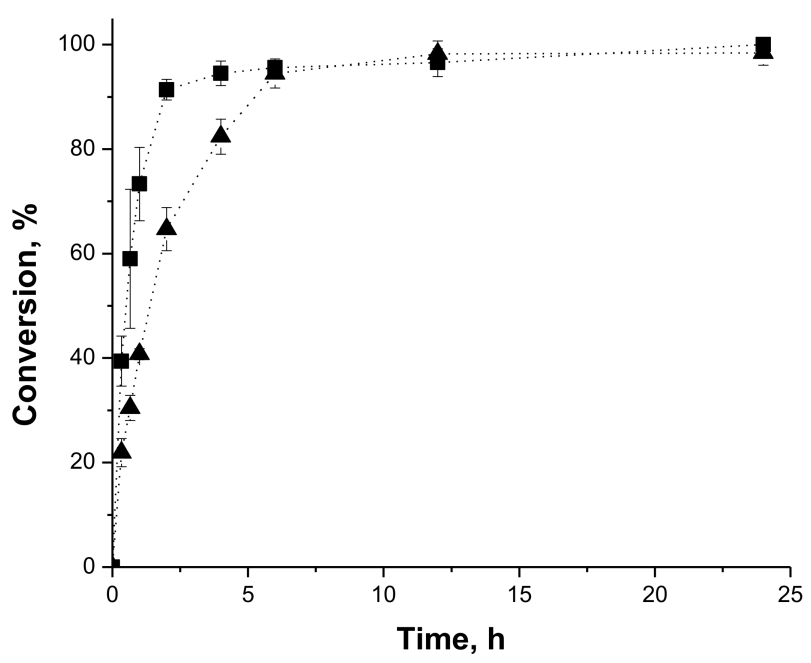

Figure 2. Time-conversion profiles of synthesis of butyl butyrate at $37^{\circ} \mathrm{C}$ catalyzed by PFL-octyl-silica in heptane, using $0.1 \mathrm{M}$ for acids and alcohols, $200 \mathrm{U} / \mathrm{g}$ of acid (esterification activity) and $20 \mathrm{~g} / \mathrm{L}$ molecular sieves. The conversions were assessed by consumption of 1-butanol by gas chromatography (squares) and butyric acid by titration (triangles).

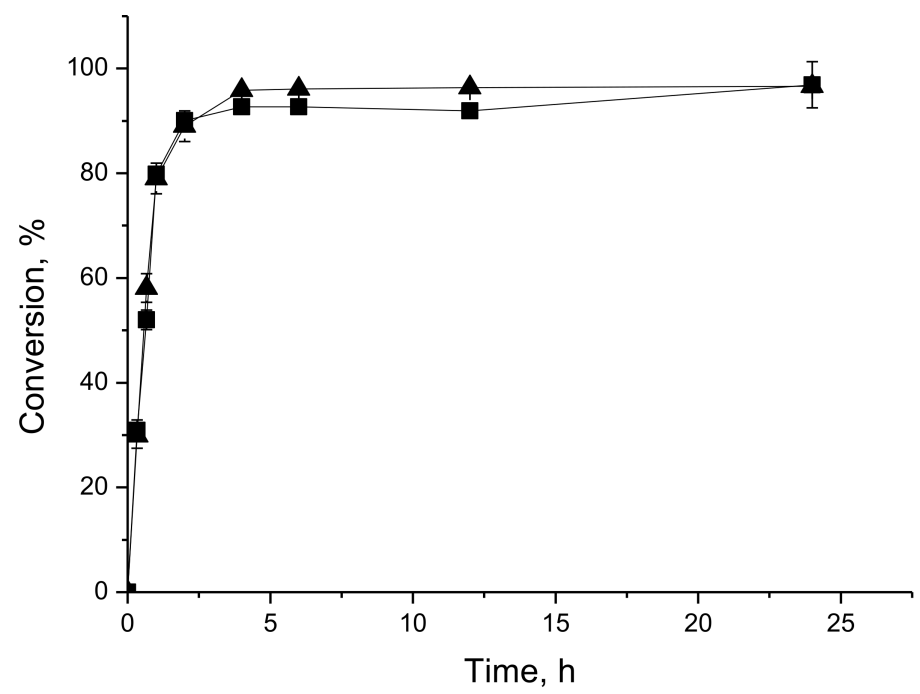

Figure 3. Time-conversion profiles of synthesis of butyl butyrate at $37{ }^{\circ} \mathrm{C}$ catalyzed by IMMCALB-T2-350, using $0.1 \mathrm{M}$ in heptane for acids and alcohols, $200 \mathrm{U} / \mathrm{g}$ of acid (esterification activity) and $20 \mathrm{~g} / \mathrm{L}$ molecular sieves. The conversions were assessed by consumption of 1-butanol by gas chromatography (squares) and butyric acid by titration (triangles).

\subsection{Syntheses of Sugar Esters}

\subsubsection{Syntheses of Fructose Oleate-Stoichiometric Ratio}

Figure 4 shows reactions courses of syntheses of fructose oleate catalyzed by IMMCALB-T2-350 and PFL-octyl-silica, using tert-butyl alcohol or tert-amyl alcohol as solvents, which are two of the most frequently employed solvents for lipase-catalyzed carbohydrate ester syntheses [32]. These solvents were chosen because they are sufficiently hydrophobic ( $\operatorname{logP}$ of 0.80 and 1.4, respectively) to prevent lipase inactivation, but sufficiently hydrophilic to dissolve the carbohydrates $[7,32,47]$. The highest conversion (79\%) was obtained with IMMCALB-T2-350 as biocatalyst and tert-butyl alcohol as solvent. This conversion was reduced to $54 \%$ when tert-amyl alcohol was used as solvent using the same 
biocatalyst. On the other hand, using PFL-octyl-silica, similar conversions (around 60\%) were obtained with both solvents.

It has been reported that interactions between organic solvent molecules and essential water for enzymatic activity in the environment of the enzyme could cause enzyme deactivation, particularly when using more hydrophilic solvents. The more hydrophobic the organic solvent is (higher $\log \mathrm{P}$ value) the more active and stable the enzyme behaves $[32,35,48]$. On the other hand, the carbohydrate capability of absorbing water could alter the essential water for the enzyme activity, reducing ester conversion [35]. In these very complex systems, composed by organic solvent, organic acid, the hydrophilic carbohydrate ( $\log \mathrm{P}=-2.23$, according to the PubChem Data Base), molecular sieves and different support surfaces, it is difficult to explain the behavior of the results with a unique phenomenon. In fact, when using immobilized lipases, the adsorption of hydrophilic substrates (e.g., carboxylic acid and alcohol), water molecules, or reaction products on the support is one of the most relevant cause of biocatalyst inactivation [21].

Neta et al. [63] also reported conversions of $70 \%$ and $74 \%$ in the syntheses of fructose oleate (stoichiometric ratio of fructose and oleic acid in ethanol as solvent) catalyzed by lipase from Candida antarctica B immobilized on chitosan and commercial lipase B from Candida antarctica, respectively. However, the authors did not report the selectivity of the reaction, since ethanol can also be a substrate in the esterification reaction. Vescovi et al. [27] reported conversions between $84 \%$ and $88 \%$ in the synthesis of fructose oleate at $55^{\circ} \mathrm{C}$ after $6 \mathrm{~h}$ of reaction catalyzed by Novozym 435 (immobilized CALB supplied by Novozymes Latin America Ltda., Araucária, PR, Brazil) and CALB immobilized onto silica bi-functionalized with octyl and glutaraldehyde moieties, using fructose and oleic acid (molar ratio of 1:5) in tert-butyl alcohol. Compared to PFL immobilized onto octyl-silica, Vescovi et al. [28] reported conversion around $40 \%$ in the synthesis of fructose oleate at $35{ }^{\circ} \mathrm{C}$ after $12 \mathrm{~h}$ of reaction using fructose and oleic acid (molar ratio of 1:5) in tert-butyl alcohol in absence of water. However, when $1 \%(v / v)$ water was added to the reaction medium, around $90 \%$ conversion was achieved. These examples show that the reaction conditions (temperature, time reaction, molar ratio of substrates, organic solvent, absence/presence of water, etc.) need to be optimized for each specific biocatalyst.

In our case, PFL-octyl-silica was better catalyst than IMMCALB-T2-350 using tert-amyl alcohol as solvent, but it was worse using tert-butyl alcohol.

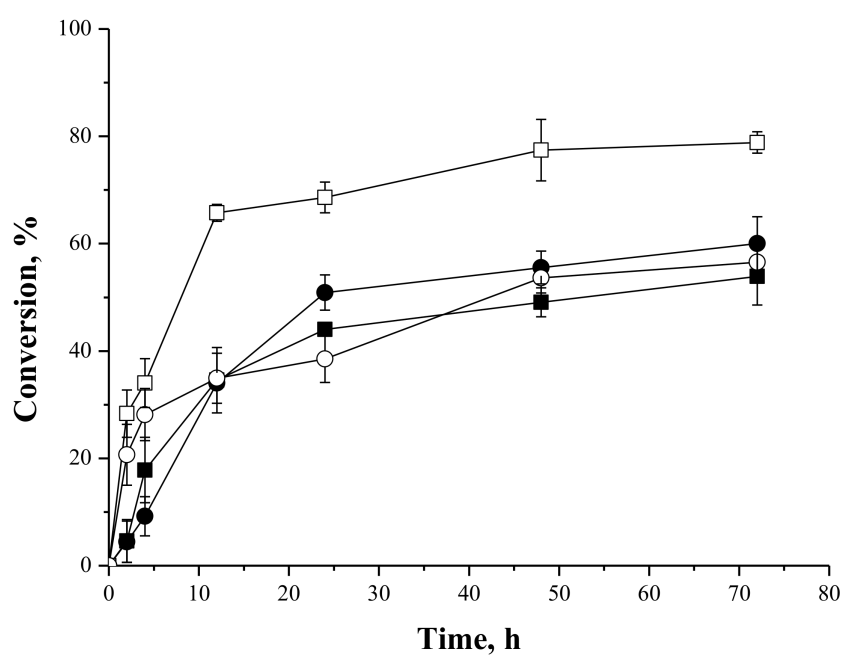

Figure 4. Oleic acid conversion as a function of time for syntheses of fructose oleate at $45^{\circ} \mathrm{C}, 250 \mathrm{rpm}$ stirring, oleic acid and fructose initial concentrations of $25 \mathrm{mM}$, using IMMCALB-T2-350 ( $\square$ ) and PFL-octyl-silica $(\bigcirc)$ in the presence of tert-butyl alcohol and IMMCALB-T2-350 (ם) and PFL-octyl-silica $(\bullet)$ in the presence of tert-amyl alcohol. For all assays $0.5 \mathrm{~g}$ of biocatalyst and $1.5 \mathrm{~g}$ of molecular sieves were used. 


\subsubsection{Syntheses of Lactose Oleate-Stoichiometric Ratio}

Figure 5 shows the profiles of the reactions courses of the synthesis of lactose oleate catalyzed by IMMCALB-T2-350 and PFL-octyl-silica, using tert-butyl alcohol and tert-amyl alcohol as solvents. The maximum conversions were around $40 \%$ after $72 \mathrm{~h}$ reaction using both solvents and biocatalysts. Lactose is a more hydrophilic carbohydrate ( $\log \mathrm{P}=-5.03$, from the PubChem Data Base) than fructose $(\log P=-2.23)$. This higher hydrophilicity of lactose could easily create a layer close to the biocatalyst stripping away essential water for catalytic activity of the enzyme and/or impairing the access of oleic acid to the enzyme active site. Besides, different affinities of lipases for different acyl acceptors in the syntheses of sugar esters have also been reported [64]. Supposedly, more bulky carbohydrate could exhibits more steric hindrances to the formation of the enzyme-substrate complex.

However, high conversion for syntheses of lactose fatty acid esters has been described. Zaidan et al. [65] reported conversions above 70\% in the acylation of lactose with capric acid (molar ratio of 2:1) at $55^{\circ} \mathrm{C}$ for $48 \mathrm{~h}$, using acetone as solvent and lipase from Candida rugosa immobilized on mica with amino groups. Neta et al. [63] also reported conversions above $80 \%$ in the synthesis of lactose oleate $\left(40^{\circ} \mathrm{C}, 72 \mathrm{~h}\right.$ reaction, stoichiometric ratio, initial reagent concentration of $\left.83.3 \mathrm{mM}\right)$ catalyzed by lipase B from Candida antarctica immobilized on chitosan and acrylic resin (commercial Novozym 435). However, ethanol was used as solvent and the authors did not report whether ethyl oleate was produced as by-product.

In our case, both solvents and biocatalyst yielded similar yields after $72 \mathrm{~h}$ of reaction under the chosen conditions. Curiously, in this reaction IMMCALB-T2-350 performance was not significantly dependent on the solvent used. That is, the binomial solvent/enzyme may change when the substrate changes, showing the complexity of the optimization of these processes.

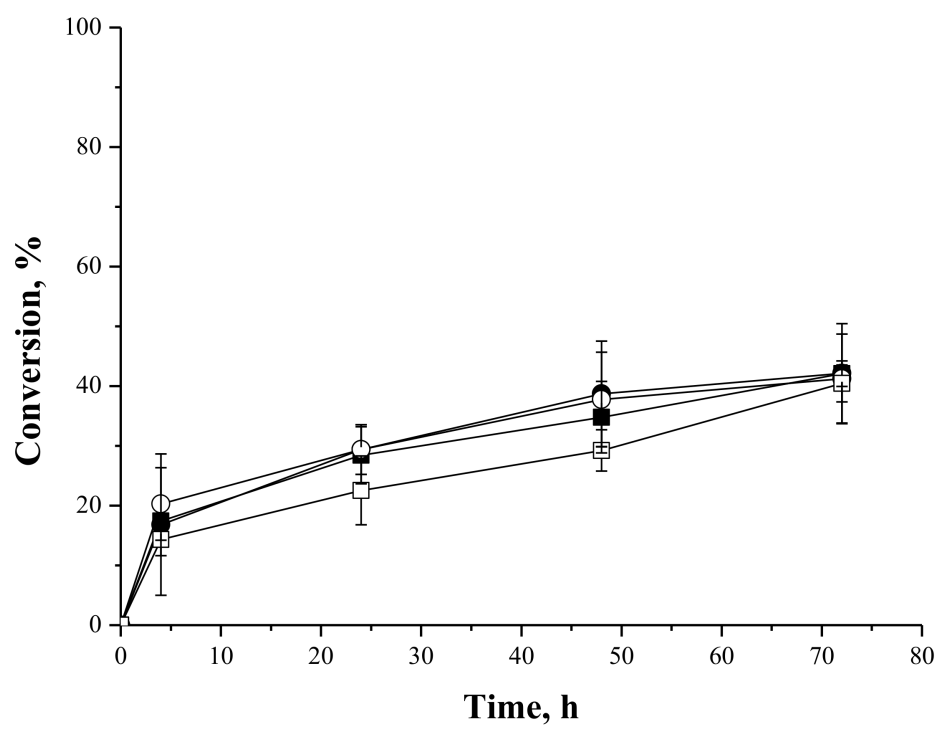

Figure 5. Oleic acid conversion as a function of time for syntheses of lactose oleate at $45^{\circ} \mathrm{C}, 250 \mathrm{rpm}$ stirring, oleic acid and lactose initial concentrations of $50 \mathrm{mM}$, using IMMCALB-T2-350 (ם) and PFL-octyl-silica (•) in the presence of tert-butyl alcohol and IMMCALB-T2-350 ( $\square$ ) and PFL-octyl-silica $(\bigcirc)$ in the presence of tert-amyl alcohol. For all assays $0.5 \mathrm{~g}$ of biocatalyst and $1.5 \mathrm{~g}$ of molecular sieves were used.

\subsubsection{Syntheses of Fructose and Lactose Laurate-Stoichiometric Ratio}

Figures 6 and 7 show the reaction courses of the syntheses of fructose and lactose laurates. Conversions of around $80 \%$ were achieved in the acylation of fructose catalyzed by IMMCALB-T2-350 when tert-amyl alcohol was used as solvent (Figure 6). Using tert-butyl alcohol as solvent, 
the conversion dropped to $40 \%$. Using PFL-octyl-silica, again there was a lack of effect of the solvent. As pointed above, IMMCALB-T2-350 showed to be more influenced by the solvent.

For the synthesis of lactose laurate (Figure 7), conversions of $40 \%$ were achieved using both solvents and IMMCALB-T2-350, while PFL-octyl-silica yields decreased to 30\%. This lower enzyme activity versus lactose was observed in the syntheses of lactose oleates (Figure 5). As pointed above, the carbohydrate hydrophilicity and/or the affinity of the lipase seem to be related to the lower conversion using lactose as acyl acceptor. In this case, the effect of the solvent was not relevant for any biocatalyst assayed, suggesting very complex relations and interferences involving, the support, the enzyme and the substrate, as pointed above.

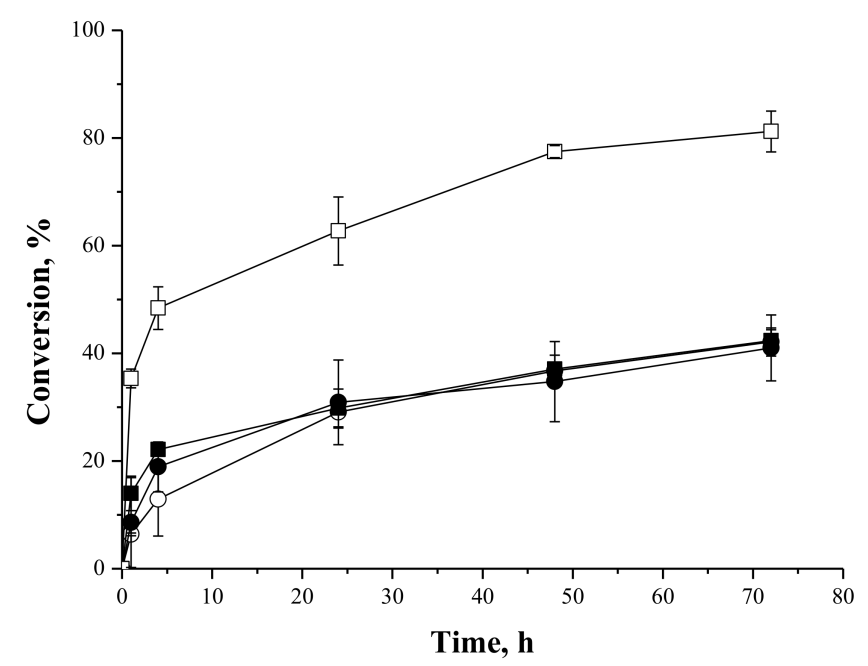

Figure 6. Lauric acid conversion as a function of time for syntheses of fructose laurate at $45^{\circ} \mathrm{C}, 72 \mathrm{~h}$, $250 \mathrm{rpm}$, oleic acid and fructose initial concentrations of $25 \mathrm{mM}$, using IMMCALB-T2-350 ( $\mathbf{\square}$ ) and PFL-octyl-silica (•) in the presence of tert-butyl alcohol and IMMCALB-T2-350 ( $\square$ ) and PFL-octyl-silica $(\bigcirc)$ in the presence of tert-amyl alcohol. For all assays $0.5 \mathrm{~g}$ of biocatalyst and $1.5 \mathrm{~g}$ of molecular sieves were used.

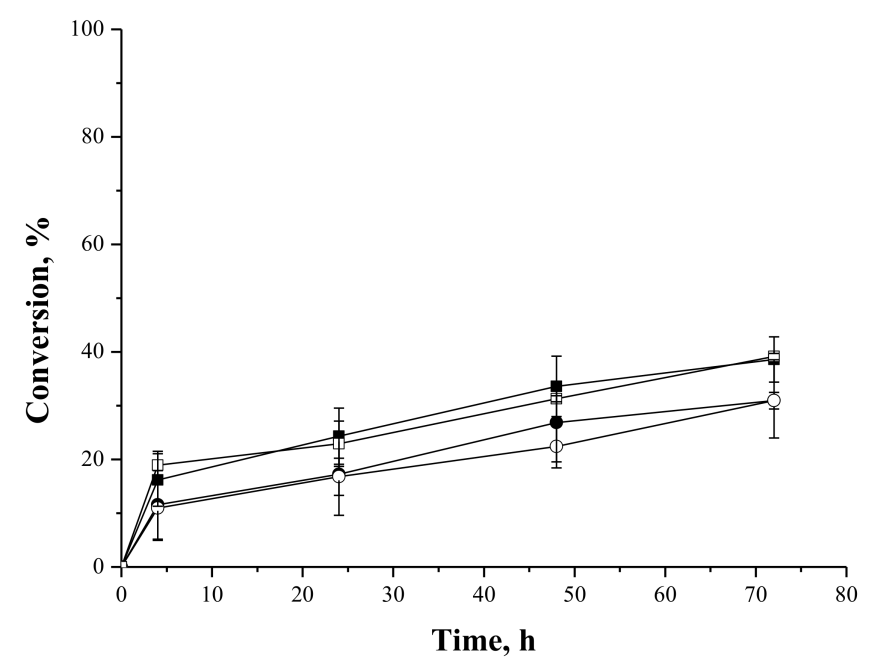

Figure 7. Lauric acid conversion as a function of time for syntheses of lactose laurate at $45^{\circ} \mathrm{C}, 72 \mathrm{~h}$, $250 \mathrm{rpm}$ stirring, oleic acid and lactose initial concentrations of $50 \mathrm{mM}$, using IMMCALB-T2-350 (ם) and PFL-octyl-silica (•) in the presence of tert-butyl alcohol and IMMCALB-T2-350 ( $\square$ ) and PFL-octyl-silica $(\bigcirc)$ in the presence of tert-amyl alcohol. For all assays $0.5 \mathrm{~g}$ of derivative and $1.5 \mathrm{~g}$ of molecular sieves were used. 


\subsubsection{Effect of the Fatty Acid:Carbohydrate Molar Ratio in the Synthesis of Oleate Fructose Esters}

Oleic acid and tert-butyl alcohol were chosen for an analysis of the influence of oleic acid:fructose molar ratio on the oleic acid conversion using different biocatalysts. Figure 8 shows the reaction courses for the syntheses of fructose oleate at different concentrations of oleic acid and fructose. It can be observed that the reaction conversion using IMMCALB-T2-350 as biocatalyst yielded $96 \%$ when a oleic acid:fructose molar ratio 1:2 $(25 / 50 \mathrm{mM})$ was used. On the other hand, using PFL-octyl-silica the reaction conversion reached only $50 \%$ at the same concentrations of substrates, slightly lower than the one obtained when the oleic acid:fructose molar ratio was 1:1 $(25 / 25 \mathrm{mM})$, i.e., around $60 \%$ conversion. In other words, excess fructose favored the reaction catalyzed by IMMCALB-T2-350, but slightly disfavored the reaction catalyzed by PFL-octyl-silica. The chemical features of the supports are very different and can explain these results. IMMCALB-T2-350 is prepared by covalent linkage of CALB onto an polyacrylic resin activated with oxirane groups (ImmobeadTM IB-350, product catalog from ChiralVision B.V., Leiden, The Netherlands), while PFL-octyl-silica is prepared by hydrophobic adsorption of PFL onto silica surface modified with octyl groups [60]. It has been described that lipase immobilized on hydrophobic supports may be released from the support at presence of organic cosolvents, high temperatures, [66] or in the presence of high concentrations of some substrates-products with surfactant properties [67-69]. In the case of PFL-octyl-silica, the reversible nature of the linkage enzyme-support in the presence of the substrate oleic acid and a product with detergent properties (fructose oleate) could desorb the enzyme from the support causing enzyme inactivation, thus reducing the reaction conversion. In fact, as it will be show below, the operational stability of the biocatalyst PFL-octyl-silica was lower than IMMCALB-T2-350 in successive batches of syntheses of fructose oleate.

When excess of oleic acid was used (molar ratio oleic acid:fructose of 2:1) the maximum yield regarding the acid should be $50 \%$ if the reaction stopped in monoester. However, reaction conversions higher than $50 \%$ were achieved using both biocatalysts, suggesting that some diesters were being produced during the reaction. This is relatively simple to explain manly considering that acyl migrations may liberate the hydroxyl group that is modified by the enzyme $[51,55,56]$.

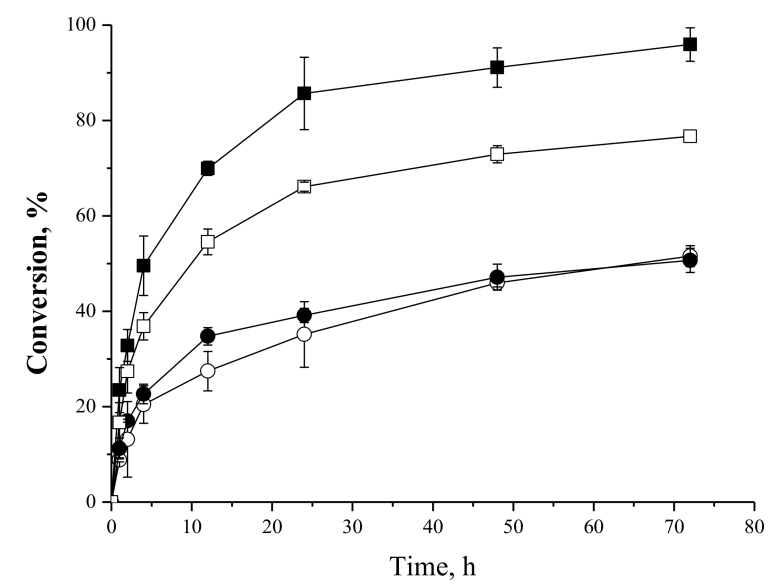

Figure 8. Oleic acid conversion as a function of time for syntheses of fructose oleate in tert-butyl alcohol as solvent at $45^{\circ} \mathrm{C}, 72 \mathrm{~h}$ reaction and $250 \mathrm{rpm}$ stirring. Molar ratio oleic acid/fructose of 1:2 (oleic acid initial concentration $25 \mathrm{mM}$, fructose initial concentration $50 \mathrm{mM}$ ) using IMMCALB-T2-350 (ם) and PFL-octyl-silica $(\bigcirc)$. Molar ratio oleic acid/fructose of 2:1 (oleic acid initial concentration $50 \mathrm{mM}$, fructose initial concentration $25 \mathrm{mM}$ ) using IMMCALB-T2-350 ( $\square$ ) and PFL-octyl-silica (•). For all assays $0.5 \mathrm{~g}$ of derivative and $1.5 \mathrm{~g}$ of molecular sieves were used.

The effect of the temperature on the conversion of syntheses of fructose oleate was evaluated in the molar ratio oleic acid:fructose of 1:2 (25 $\mathrm{mM}$ of oleic acid and $50 \mathrm{mM}$ of fructose) for syntheses 
catalyzed by IMMCALB-T2-350, and stoichiometric ratio (25 mM of fructose and oleic acid) for syntheses catalyzed by PFL-octyl-silica. Figure 9 shows the reaction courses for syntheses of fructose oleate carried out at $45{ }^{\circ} \mathrm{C}$ and $55^{\circ} \mathrm{C}$.

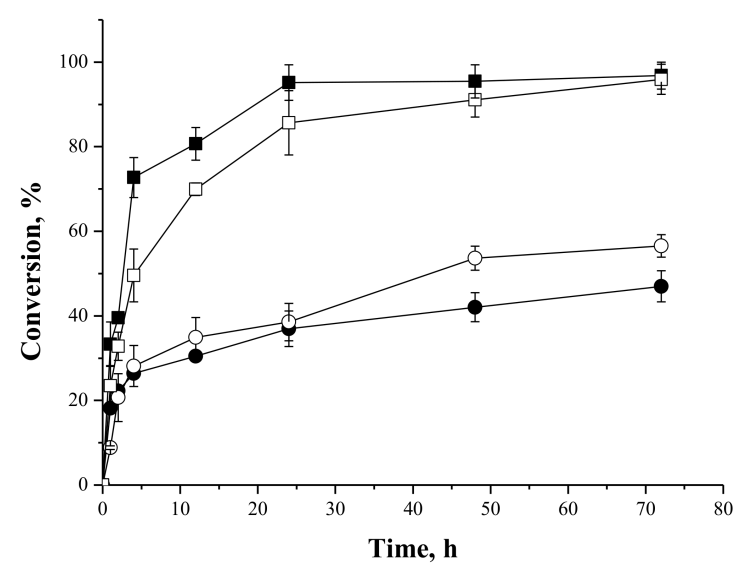

Figure 9. Oleic acid conversion as function of time for syntheses of fructose oleate using tert-butyl alcohol as solvent, $72 \mathrm{~h}$ reaction, $250 \mathrm{rpm}$ stirring, oleic acid initial concentration $25 \mathrm{mM}$, fructose initial concentration $25 \mathrm{mM}$, using PFL-octyl-silica at $45^{\circ} \mathrm{C}(\bigcirc)$, PFL-octyl-silica at $55^{\circ} \mathrm{C}(\bullet)$ and oleic acid initial concentration $25 \mathrm{mM}$, fructose initial concentration $50 \mathrm{mM}$, using IMMCALB-T2-350 at $45{ }^{\circ} \mathrm{C}(\square)$ and $55{ }^{\circ} \mathrm{C}(\boldsymbol{\square})$. For all assays $0.5 \mathrm{~g}$ of derivative and $1.5 \mathrm{~g}$ molecular sieves were used.

At $55{ }^{\circ} \mathrm{C}$ the conversion reached $96 \%$ within $24 \mathrm{~h}$ using IMMCALB-T2-350 as biocatalyst, while using PFL-octyl-silica the conversion was slightly reduced from 57 (after $72 \mathrm{~h}$ at $45^{\circ} \mathrm{C}$ ) to $46 \%$ (after $72 \mathrm{~h}$ at $55^{\circ} \mathrm{C}$ ), although at shorter times the reaction progressed more rapidly at $55^{\circ} \mathrm{C}$. These results could be related to the lower stability of the PFL-octyl-silica due to enzyme desorption from the support surface, followed by enzyme inactivation.

\subsubsection{Effect of the Biocatalyst Mass}

Figure 10 shows the oleic acid consumption during the syntheses of fructose oleate with different derivative masses $(0.25,0.5$ and $1.0 \mathrm{~g})$ using initial oleic acid and fructose concentrations of $25 \mathrm{mM}$ when utilizing PFL-octyl-silica as biocatalyst, and oleic acid and fructose initial concentrations of 25 and $50 \mathrm{mM}$, respectively, when employing IMMCALB-T2-350 as catalyst, using tert-butanol as solvent.

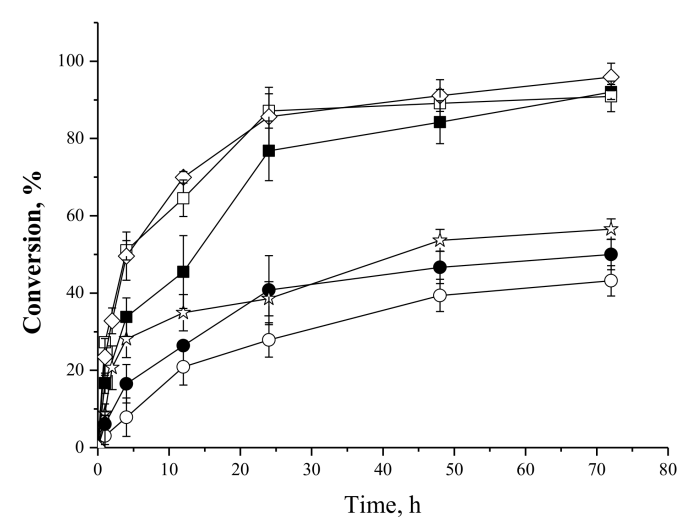

Figure 10. Oleic acid conversion as a function of time on the syntheses of fructose oleate at $45{ }^{\circ} \mathrm{C}$, $250 \mathrm{rpm}$ stirring, fructose initial concentration $25 \mathrm{mM}$, oleic acid initial concentration $25 \mathrm{mM}$ using $0.25 \mathrm{~g}(\bigcirc), 0.5 \mathrm{~g}\left(\aleph^{2}\right)$ and $1.0 \mathrm{~g}(\bullet)$ of PFL-octyl-silica and oleic acid initial concentration $25 \mathrm{mM}$, fructose initial concentration $50 \mathrm{mM}$ using $0.25 \mathrm{~g}(\mathbf{\square}), 0.5 \mathrm{~g}(\diamond)$ and $1.0 \mathrm{~g}(\square)$ of IMMCALB-T2-350, using tert-butyl alcohol as solvent and $1.5 \mathrm{~g}$ molecular sieves for all synthesis reactions. 
For the reactions catalyzed by IMMCALB-T2-350 the behavior was typical of enzyme catalyzed reactions: the initial rate increased with increasing the mass of biocatalyst from 0.25 to $0.5 \mathrm{~g}$, but reaching similar conversions ( 90 to $96 \%$ ) for $72 \mathrm{~h}$ reaction. When using a higher mass of biocatalyst $(1.0 \mathrm{~g})$, the reaction rate did not significantly change, probably because the biocatalyst particles aggregated and produced merged particles with higher diffusional limitations, more water retention, etc. In the reactions catalyzed by PFL-octyl-silica, the reaction rate increased when the biocatalyst mass increased from 0.25 to $0.5 \mathrm{~g}$, but decreased when the mass was increased from 0.5 to $1.0 \mathrm{~g}$, very likely due to the same problem.

\subsubsection{Operational Stability of the Biocatalysts in the Syntheses of Fructose Oleate}

Figure 11 shows the operational stability of the biocatalysts PFL-octyl-silica and IMMCALB-T2-350 in successive batches of $48 \mathrm{~h}$ in the synthesis of fructose oleate at $45^{\circ} \mathrm{C}$. The performance of both biocatalysts was reduced at $45^{\circ} \mathrm{C}$, but more accentuated for PFL-octyl-silica: the conversion was reduced to $50 \%$ after the fifth reaction cycle, while using IMMCALB-T2-350 the conversion was only reduced to $80 \%$. It may be assumed that enzyme desorption from the octyl-silica support occurs in the presence of products with detergent properties (oleic acid and fructose oleate) [67-69].

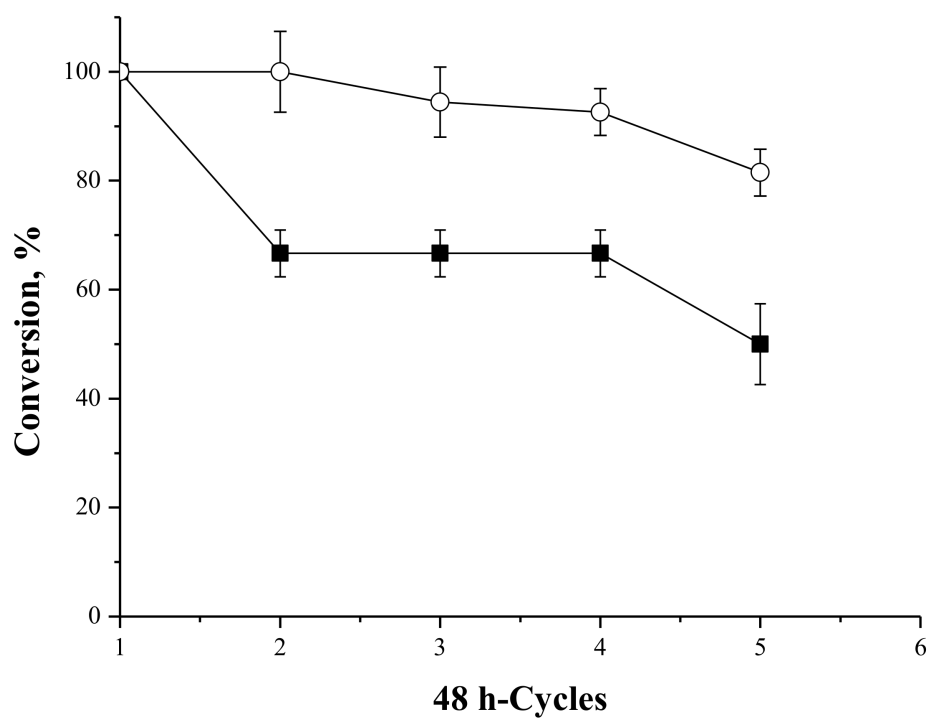

Figure 11. Relative conversion as a function of the number of recycles for syntheses of fructose oleate at $45^{\circ} \mathrm{C}$, cycles of $48 \mathrm{~h}$ reaction, $250 \mathrm{rpm}$ stirring, $25 \mathrm{mM}$ of initial concentrations of fructose and oleic acid using PFL-octyl-silica ( $\mathbf{\square}$ ) and oleic acid initial concentration of $25 \mathrm{mM}$, fructose initial concentration of $50 \mathrm{mM}$ using IMMCALB-T2-350 ( $)$. All assays were carried out in tert-butyl alcohol as solvent, $0.5 \mathrm{~g}$ of biocatalyst and $1.5 \mathrm{~g}$ molecular sieves. The conversion for the first cycle was considered as $100 \%$.

\section{Materials and Methods}

\subsection{Materials}

Lipase from Pseudomonas fluorescens (PFL) was acquired from Sigma-Aldrich Co. (St. Louis, MO, USA). Commercial immobilized lipases from Candida antarctica type B (CALB, IMMCALB-T2-350), Thermomyces lanuginosus (Lipolase, IMMTLL-T2-150) and Pseudomonas fluorescens (Amano AK, IMMAPF-T2-150) were acquired from ChiralVision (Leiden, The Netherlands). All these commercial lipases are covalently attached to dry acrylic beads (Immobead ${ }^{\mathrm{TM}}$ IB-150 or IB-350-crosslinked copolymer of methacrylate exhibiting oxirane groups-particle size 150-200 micrometer or 300-700 micrometer, respectively) Product catalog (ChiralVision B.V., Leiden, The Netherlands). Macroporous silica (Immobead S60S, particle size of 60-200 micrometer) was attained from 
ChiralVision (Supplementary material). Molecular sieve UOP type $3 \AA$ ( $\mathrm{rod}$, size 1/16 in.) was purposed by Sigma-Aldrich Co. 2-Methyl-2-butanol (tert-amyl alcohol), 1-hexanol and 1-butanol were purchased from Sigma-Aldrich Co. Ethanol (99.7\%) was purchased from JT Baker (Phillipsburg, NJ, USA). 2-Methyl-2-propanol (tert-butyl alcohol), lactose and lauric acid were purchased from Vetec (Rio de Janeiro, Brazil). Heptane, isoamyl alcohol, fructose and oleic acid were purchased from Synth (São Paulo, Brazil). Acetic acid was purchased from Qhemis (Sao Paulo, Brazil).

\subsection{Production of Octyl-Silica Support}

The chemical modification of silica with octyl groups was performed according to Tani and Suzuki [70]. Firstly, silica particles were incubated in $0.1 \mathrm{M}$ hydrochloric acid and washed with distilled water until the $\mathrm{pH}$ was neutral. Afterwards, the particles were dried at $200{ }^{\circ} \mathrm{C}$ for $5 \mathrm{~h}$. One gram of dried silica was maintained under reflux with $20 \mathrm{~mL}$ of a mixture of toluene and octyltriethoxysilane (volume ratio of $10: 1$ ) at $85^{\circ} \mathrm{C}$. After $3 \mathrm{~h}$, the suspension was filtered and the support was thoroughly washed with toluene, methanol, and distilled water. Finally, the support was dried at room temperature for $24 \mathrm{~h}$. The activated support, named octyl-silica, was used for the immobilization of PFL.

\subsection{Immobilization of PFL on Octyl-Silica}

Octyl-silica particles were suspended in an enzymatic solution prepared in $5 \mathrm{mM}$ sodium phosphate ( $\mathrm{pH}$ 7.0) in a support:enzymatic solution ratio of 1:19 $(w / v)$. Two derivatives were prepared: a low-loaded derivative ( $5 \mathrm{mg}$ protein/g support) and a high-loaded derivative ( $40 \mathrm{mg}$ protein $/ \mathrm{g}$ support), although the loading capability of this support is around $168 \mathrm{mg}$ protein/g support [60]. The suspension was gently stirred in an orbital shaker at $25^{\circ} \mathrm{C}$ for $24 \mathrm{~h}$ [39]. PFL-octyl-silica biocatalyst was filtered and washed with Milli-Q water. In order to monitor the enzyme immobilization, enzyme hydrolytic activity versus emulsified olive oil was assessed in the supernatant solution and in a control enzyme solution incubated under the same conditions, but without support. The immobilization parameters (immobilization yield and recovered activity) were calculated as previously described [60].

\subsection{Synthesis of Flavor Esters}

The syntheses of flavor esters were performed according to Abbas and Comeau [3] in closed glass flasks. Briefly, $10 \mathrm{~mL}$ of a solution of short-chain acids (acetic or butyric acid) and alcohols (1-butanol, 1-hexanol, ethanol or isoamyl alcohol) were prepared in heptane to a final concentration of $0.1 \mathrm{M}$ (for both acid and alcohol). The esterification reactions were performed at $37^{\circ} \mathrm{C}$ under $250 \mathrm{rpm}$ stirring in the presence of molecular sieves $(20 \mathrm{~g} / \mathrm{L})$. A load of $200 \mathrm{U} / \mathrm{g}$ of acid (in terms of esterification activity as describe below) was used for all biocatalysts: home-made PFL-octyl-silica (low-loaded derivative, i.e., $5 \mathrm{mg}$ protein/g support) and commercial immobilized lipases (IMMCALB-T2-350, IMMTLL-T2-150 and IMMAPF-T2-150).

The reaction conversion (Equation (1)) was assessed from the results of acid consumption by titration with $0.025 \mathrm{M} \mathrm{KOH}$. Samples of $0.5 \mathrm{~mL}$ of the reaction medium were takenat regular time periods and diluted with $10 \mathrm{~mL}$ of a solution of acetone:ethanol $(1: 1 v / v)$ containing phenolphthalein as the $\mathrm{pH}$ indicator. All assays were performed in triplicate:

$$
C(\%)=\frac{\text { ol }_{t=0}-\mathrm{mol}_{t=t}}{m o l_{t=0}} \times 100
$$

where $C(\%)$ is the reaction conversion, $m o l_{t=0}$ is the initial number of moles of fatty acid and $m o l_{t=t}$ is the number of moles of fatty acid at time $t$.

In order to evaluate whether the titration was suitable to monitor the reaction, the synthesis of butyl butyrate was also followed by gas chromatography. Samples of $1 \mu \mathrm{L}$ were injected in a HP5890 Gas Chromatograph (Hewlett-Packard Company, Palo Alto, CA, USA) equipped with a 
flame ionization detector, using nitrogen as carrier gas and a crossbond acid deactivated Carbowax polyethelene glycol column $(15 \mathrm{~m} \times 0.32 \mathrm{~mm} \times 0.45 \mathrm{~m}$, Restek Corporation, (Bellefonte, PA, USA)). In this case, the reaction conversion was calculated based on the 1-butanol consumption (in this case, all experiments were carried out using molar ratio butyric acid/1-butanol of 1:1).

\subsection{Synthesis of Sugar Esters}

The syntheses of sugar esters were carried out according to Paula et al. [71] in closed glass flasks. Briefly, $10 \mathrm{~mL}$ of a solution of fructose $(25$ or $50 \mathrm{mM})$ or lactose $(50 \mathrm{mM})$ were prepared by dissolving the carbohydrates in organic solvents (tert-butyl alcohol or tert-amyl alcohol). Afterwards, oleic or lauric acids were added to final concentrations of 25 or $50 \mathrm{mM}$. The reactions were carried out in the presence of $1.5 \mathrm{~g}$ of molecular sieves $(150 \mathrm{~g} / \mathrm{L})$, in order to reduce and control the water activity in the reaction medium. Adachi and Kobayashi [47] reported an increase in the equilibrium conversion for lauroyl mannose synthesis adding to the system until $100 \mathrm{~g} / \mathrm{L}$ of molecular sieve 3A. In this work, we adopt a concentration of $150 \mathrm{~g} / \mathrm{L}$ to guarantee water removal from the reaction system. The biocatalysts used in these reactions were PFL-octyl-silica (high-loaded, i.e., $40 \mathrm{mg}$ protein/g support) and the commercial immobilized lipase from Candida antarctica (IMMCALB-T2-350), using biocatalyst masses of $0.25,0.5$ and $1.0 \mathrm{~g}$. The reactions were carried out in triplicate at 45 or $55^{\circ} \mathrm{C}$ for $72 \mathrm{~h}$ under $250 \mathrm{rpm}$ stirring. The reaction conversion was monitored by titration with $0.01 \mathrm{M} \mathrm{KOH}$ solution.

\subsection{Operational Stability of the Biocatalysts}

The operational stability of the biocatalysts was studied in the syntheses of butyl butyrate and fructose oleate, as described below.

\subsubsection{Flavor Ester (Butyl Butyrate)}

PFL-octyl-silica, IMMCALB-T2-350, IMMTLL-T2-150 and IMMAPF-T2-150 were used in eight $24 \mathrm{~h}$-cycles of synthesis of butyl butyrate at $37^{\circ} \mathrm{C}$ under $250 \mathrm{rpm}$ stirring, using heptane as solvent, acid and alcohol concentrations of $0.1 \mathrm{M}$ and $20 \mathrm{~g} / \mathrm{L}$ molecular sieve. The reaction volume and the enzyme load were $10 \mathrm{~mL}$ and $200 \mathrm{U} / \mathrm{g}$ butyric acid (in terms of esterification activity as described below), respectively. After each cycle, the biocatalysts were washed with heptane before being used in a new reaction cycle. The conversion of the reaction after $24 \mathrm{~h}$ was calculated from the consumption of acid, monitored by titration. All assays were performed in duplicate.

\subsubsection{Sugar Ester (Fructose Oleate)}

PFL-octyl-silica and IMMCALB-T2-350 were employed in five $48 \mathrm{~h}$-cycles of synthesis of fructose oleate employing $0.5 \mathrm{~g}$ of biocatalyst, $10 \mathrm{~mL}$ of tert-butyl alcohol as solvent, and $1.5 \mathrm{~g}$ of molecular sieves at $45{ }^{\circ} \mathrm{C}$ under $250 \mathrm{rpm}$ stirring. The initial molar ratio fructose/oleic acid was 25:25 (mM) for PFL-octyl silica and 25:50 (mM) for IMMCALB-T2-350. After each 48 h-batch, the biocatalysts were washed with tert-butanol and used in a new esterification. The conversion of the reaction was calculated from the consumption of acid, monitored by titration. All assays were carried out in triplicate.

\subsection{Esterification Activity Assay}

The esterification activity of the biocatalysts was measured at $37^{\circ} \mathrm{C}$ under $250 \mathrm{rpm}$ stirring in closed glass flasks, using 1-butanol and butyric acid (both at $0.1 \mathrm{M})$ in heptane (10 $\mathrm{mL}$ reaction volume) as acceptor and donor of acyl group, respectively [71]. Samples were taken from the reaction medium at the defined times (up to $40 \mathrm{~min}$ ) for quantification of butyric acid by titration with $0.0105 \mathrm{M} \mathrm{KOH}$ solution. One unit of esterification activity was defined as the consumption of $1 \mu \mathrm{mol}$ of butyric acid per minute under the reaction conditions. 


\section{Conclusions}

Lipase from Pseudomonas fluorescens immobilized on silica modified with octyl groups (PFL-octyl-silica biocatalyst) presented similar performance and operational stability compared to the covalent commercial preparation of the same lipase or other lipases in the ester syntheses with flavor properties. On the other hand, different interactions between biocatalysts/medium/substrate might have caused different catalytic behavior of the enzyme during sugar ester synthesis. Such differences might be related either to the nature of the enzymes or interactions between substrates and the biocatalyst itself (support and/or enzyme). In the syntheses of sugar fatty acid esters, PFL-octyl-silica reached lower conversion and showed lower operational stability compared to the CALB IM biocatalyst.

Supplementary Materials: The following are available online.

Acknowledgments: This work was supported by the São Paulo Research Foundation (FAPESP) (grant numbers \#2011/23194-0, \#2016/10636-8), Brazilian National Research Council—CNPq (Lionete Nunes de Lima' doctorate fellowship), and Spanish MINECO (Project CTQ2017-86170-R). The help and comments from Ángel Berenguer (Instituto de Materiales, Universidad de Alicante) are gratefully recognized.

Author Contributions: Lionete Nunes de Lima performed the experiments; Adriano Aguiar Mendes designed the experiments of synthesis of short-chain carboxylic esters; Raquel de Lima Camargo Giordano, Roberto Fernandez-Lafuente and Paulo Waldir Tardioli designed the experiments and wrote the paper.

Conflicts of Interest: The authors declare no conflict of interest.

\section{References}

1. Liu, S.-Q.; Holland, R.; Crow, V.L. Esters and their biosynthesis in fermented dairy products: A review. Int. Dairy J. 2004, 14, 923-945. [CrossRef]

2. Sumby, K.M.; Grbin, P.R.; Jiranek, V. Microbial modulation of aromatic esters in wine: Current knowledge and future prospects. Food Chem. 2010, 121, 1-16. [CrossRef]

3. Abbas, H.; Comeau, L. Aroma synthesis by immobilized lipase from Mucor sp. Enzym. Microb. Technol. 2003, 32, 589-595. [CrossRef]

4. Khan, N.R.; Rathod, V.K. Enzyme catalyzed synthesis of cosmetic esters and its intensification: A review. Process Biochem. 2015, 50, 1793-1806. [CrossRef]

5. Hasan, F.; Shah, A.A.; Hameed, A. Industrial applications of microbial lipases. Enzym. Microb. Technol. 2006, 39, 235-251. [CrossRef]

6. Kiss, M.A.; Sefanovits-Bányai, É.; Tóth, Á.; Boross, L. Extractive Synthesis of Ethyl-Oleate Using Alginate Gel Co-Entrapped Yeast Cells and Lipase Enzyme. Eng. Life Sci. 2004, 4, 460-464. [CrossRef]

7. Kobayashi, T. Lipase-catalyzed syntheses of sugar esters in non-aqueous media. Biotechnol. Lett. 2011, 33, 1911-1919. [CrossRef] [PubMed]

8. Gumel, A.M.; Annuar, M.S.M.; Heidelberg, T.; Chisti, Y. Lipase mediated synthesis of sugar fatty acid esters. Process Biochem. 2011, 46, 2079-2090. [CrossRef]

9. Kosaric, N. Biosurfactants in industry. Pure Appl. Chem. 1992, 64, 1731-1737. [CrossRef]

10. Bidjou-Haiour, C.; Klai, N. Lipase catalyzed synthesis of fatty acid xylose esters and their surfactant properties. Asian J. Chem. 2013, 25, 4347-4350. [CrossRef]

11. Patil, D.; De Leonardis, A.; Nag, A. Synthesis of Biosurfactants From Natural Resources. J. Food Biochem. 2011, 35, 747-758. [CrossRef]

12. Sutili, F.K.; Ruela, H.S.; Leite, S.G.F.; Miranda, L.S.D.M.; Leal, I.C.R.; de Souza, R.O.M.A. Lipase-catalyzed esterification of steric hindered fructose derivative by continuous flow and batch conditions. J. Mol. Catal. B Enzym. 2013, 85, 37-42. [CrossRef]

13. Zhang, X.; Nie, K.; Wang, M.; Liu, L.; Li, K.; Wang, F.; Tan, T.; Deng, L. Site-specific xylitol dicaprate ester synthesized by lipase from Candida sp. 99-125 with solvent-free system. J. Mol. Catal. B Enzym. 2013, 89, 61-66. [CrossRef]

14. Ferrer, M.; Soliveri, J.; Plou, F.J; López-Cortés, N.; Reyes-Duarte, D.; Christensen, M.; Copa-Patiño, J.L.; Ballesteros, A. Synthesis of sugar esters in solvent mixtures by lipases from Thermomyces lanuginosus and Candida antarctica B, and their antimicrobial properties. Enzym. Microb. Technol. 2005, 36, 391-398. [CrossRef] 
15. Yan, Y.; Bornscheuer, U.T.; Stadler, G.; Lutz-Wahl, S.; Otto, R.T.; Reuss, M.; Schmid, R.D. Regioselective lipase-catalyzed synthesis of glucose ester on a preparative scale. Eur. J. Lipid Sci. Technol. 2001, 103, 583-587. [CrossRef]

16. Boscolo, M. Sucrochemistry: Synthesis and potentialities for applications of some sucrose chemical derivates. Quim. Nova 2003, 26, 906-912. [CrossRef]

17. El Seoud, O.A.; Koschella, A.; Fidale, L.C.; Dorn, S.; Heinze, T. Applications of ionic liquids in carbohydrate chemistry: A window of opportunities. Biomacromolecules 2007, 8, 2629-2647. [CrossRef] [PubMed]

18. Abdulmalek, E.; Hamidon, N.F.; Abdul Rahman, M.B. Optimization and characterization of lipase catalysed synthesis of xylose caproate ester in organic solvents. J. Mol. Catal. B Enzym. 2016, 132, 1-4. [CrossRef]

19. De Castro, H.F.; Mendes, A.A.; Dos Santos, J.C.; De Aguiar, C.L. Modificação de óleos e gorduras por biotransformação. Quim. Nova 2004, 27, 146-156. [CrossRef]

20. Kumari, A.; Mahapatra, P.; Garlapati, V.K.; Banerjee, R. Enzymatic transesterification of Jatropha oil. Biotechnol. Biofuels 2009, 2, 1. [CrossRef] [PubMed]

21. Fallavena, L.P.; Antunes, F.H.F.; Alves, J.S.; Paludo, N.; Ayub, M.A.Z.; Fernandez-Lafuente, R.; Rodrigues, R.C. Ultrasound technology and molecular sieves improve the thermodynamically controlled esterification of butyric acid mediated by immobilized lipase from Rhizomucor miehei. RSC Adv. 2014, 4, 8675. [CrossRef]

22. Mai, N.L.; Ahn, K.; Bae, S.W.; Shin, D.W.; Morya, V.K.; Koo, Y.-M. Ionic liquids as novel solvents for the synthesis of sugar fatty acid ester. Biotechnol. J. 2014, 1-8. [CrossRef] [PubMed]

23. Shi, Y.G.; Li, J.R.; Chu, Y.H. Enzyme-catalyzed regioselective synthesis of sucrose-based esters. J. Chem. Technol. Biotechnol. 2011, 86, 1457-1468. [CrossRef]

24. Reetz, M.T. Lipases as practical biocatalysts. Curr. Opin. Chem. Biol. 2002, 6, 145-150. [CrossRef]

25. Abdulmalek, E.; Mohd Saupi, H.S.; Tejo, B.A.; Basri, M.; Salleh, A.B.; Raja Abd Rahman, R.N.Z.; Abdul Rahman, M.B. Improved enzymatic galactose oleate ester synthesis in ionic liquids. J. Mol. Catal. B Enzym. 2012, 76, 37-43. [CrossRef]

26. Vescovi, V.; dos Santos, J.B.C.; Tardioli, P.W. Porcine pancreatic lipase hydrophobically adsorbed on octyl-silica: A robust biocatalyst for syntheses of xylose fatty acid esters. Biocatal. Biotransform. 2017, 35. [CrossRef]

27. Vescovi, V.; Kopp, W.; Guisán, J.M.; Giordano, R.L.C.; Mendes, A.A.; Tardioli, P.W. Improved catalytic properties of Candida antarctica lipase B multi-attached on tailor-made hydrophobic silica containing octyl and multifunctional amino- glutaraldehyde spacer arms. Process Biochem. 2016, 51, 2055-2066. [CrossRef]

28. Vescovi, V.; Giordano, R.L.C.; Mendes, A.A.; Tardioli, P.W. Immobilized Lipases on Functionalized Silica Particles as Potential Biocatalysts for the Synthesis of Fructose Oleate in an Organic Solvent/Water System. Molecules 2017, 22, 212. [CrossRef] [PubMed]

29. Chamouleau, F.; Coulon, D.; Girardin, M.; Ghoul, M. Influence of water activity and water content on sugar esters lipase-catalyzed synthesis in organic media. J. Mol. Catal. B Enzym. 2001, 11, 949-954. [CrossRef]

30. Chang, S.W.; Shaw, J.F. Biocatalysis for the production of carbohydrate esters. New Biotechnol. 2009, 26, 109-116. [CrossRef] [PubMed]

31. Coulon, D.; Ismail, A.; Girardin, M.; Rovel, B.; Ghoul, M. Effect of different biochemical parameters on the enzymatic synthesis of fructose oleate. J. Biotechnol. 1996, 51, 115-121. [CrossRef]

32. Degn, P.; Zimmermann, W. Optimization of carbohydrate fatty acid ester synthesis in organic media by a lipase from Candida antarctica. Biotechnol. Bioeng. 2001, 74, 483-491. [CrossRef] [PubMed]

33. Neta, N.S.; Teixeira, J.A.; Rodrigues, L.R. Sugar Ester Surfactants: Enzymatic Synthesis and Applications in Food Industry. Crit. Rev. Food Sci. Nutr. 2015, 55, 595-610. [CrossRef] [PubMed]

34. Šabeder, S.; Habulin, M.; Knez, Ž. Lipase-catalyzed synthesis of fatty acid fructose esters. J. Food Eng. 2006, 77, 880-886. [CrossRef]

35. Tarahomjoo, S.; Alemzadeh, I. Surfactant production by an enzymatic method. Enzym. Microb. Technol. 2003, 33, 33-37. [CrossRef]

36. Bezbradica, D.; Mijin, D.; Šiler-Marinković, S.; Knežević, Z. The effect of substrate polarity on the lipase-catalyzed synthesis of aroma esters in solvent-free systems. J. Mol. Catal. B Enzym. 2007, 45, 97-101. [CrossRef]

37. Verger, R. "Interfacial activation" of lipases: Facts and artifacts. Trends Biotechnol. 1997, 15, 32-38. [CrossRef] 
38. Brzozowski, A.M.; Derewenda, U.; Derewenda, Z.S.; Dodson, G.G.; Lawson, D.M.; Turkenburg, J.P.; Bjorkling, F.; Huge-Jensen, B.; Patkar, S.A.; Thim, L. A model for interfacial activation in lipases from the structure of a fungal lipase-inhibitor complex. Nature 1991, 351, 491. [CrossRef] [PubMed]

39. Bastida, A.; Sabuquillo, P.; Armisen, P.; Fernández-Lafuente, R.; Huguet, J.; Guisán, J.M. A single step purification, immobilization, and hyperactivation of lipases via interfacial adsorption on strongly hydrophobic supports. Biotechnol. Bioeng. 1998, 58, 486-493. [CrossRef]

40. Palomo, J.M.; Muñoz, G.; Fernández-Lorente, G.; Mateo, C.; Fernández-Lafuente, R.; Guisán, J.M. Interfacial adsorption of lipases on very hydrophobic support (octadecyl-Sepabeads): Immobilization, hyperactivation and stabilization of the open form of lipases. J. Mol. Catal. B Enzym. 2002, 19-, 279-286. [CrossRef]

41. Martinelle, M.; Holmquist, M.; Hult, K. On the interfacial activation of Candida antarctica lipase A and B as compared with Humicola lanuginosa lipase. Biochim. Biophys. Acta 1995, 1258, 272-276. [CrossRef]

42. Palomo, J.M.; Ortiz, C.; Fuentes, M.; Fernández-Lorente, G.; Gusian, J.M.; Fernandez-Lafuente, R. Use of immobilized lipases for lipase purification via specific lipase-lipase interactions. J. Chromatogr. A 2004, 1038, 267-273. [CrossRef] [PubMed]

43. Palomo, J.M.; Ortiz, C.; Fernández-Lorente, G.; Fuentes, M.; Guisán, J.M.; Fernández-Lafuente, R. Lipase-lipase interactions as a new tool to immobilize and modulate the lipase properties. Enzym. Microb. Technol. 2005, 36, 447-454. [CrossRef]

44. Fernandez-Lafuente, R.; Armisén, P.; Sabuquillo, P.; Fernández-Lorente, G.; Guisán, J.M. Immobilization of lipases by selective adsorption on hydrophobic supports. Chem. Phys. Lipids 1998, 93, 185-197. [CrossRef]

45. Lima, L.N.; Aragon, C.C.; Mateo, C.; Palomo, J.M.; Giordano, R.L.C.; Tardioli, P.W.; Guisan, J.M.; Fernandez-Lorente, G. Immobilization and stabilization of a bimolecular aggregate of the lipase from Pseudomonas fluorescens by multipoint covalent attachment. Process Biochem. 2013, 48, 118-123. [CrossRef]

46. Manoel, E.A.; dos Santos, J.C.S.; Freire, D.M.G.; Rueda, N.; Fernandez-Lafuente, R. Immobilization of lipases on hydrophobic supports involves the open form of the enzyme. Enzym. Microb. Technol. 2015, 71. [CrossRef] [PubMed]

47. Adachi, S.; Kobayashi, T. Synthesis of esters by immobilized-lipase-catalyzed condensation reaction of sugars and fatty acids in water-miscible organic solvent. J. Biosci. Bioeng. 2005, 99, 87-94. [CrossRef] [PubMed]

48. Paiva, A.L.; Balcão, V.M.; Malcata, F.X. Kinetics and mechanisms of reactions catalyzed by immobilized lipases. Enzym. Microb. Technol. 2000, 27, 187-204. [CrossRef]

49. Alves, J.S.; Garcia-Galan, C.; Schein, M.F.; Silva, A.M.; Barbosa, O.; Ayub, M.A.Z.; Fernandez-Lafuente, R.; Rodrigues, R.C. Combined effects of ultrasound and immobilization protocol on butyl acetate synthesis catalyzed by CALB. Molecules 2014, 19, 9562-9576. [CrossRef] [PubMed]

50. Martins, A.B.; Schein, M.F.; Friedrich, J.L.R.; Fernandez-Lafuente, R.; Ayub, M.A.Z.; Rodrigues, R.C. Ultrasound-assisted butyl acetate synthesis catalyzed by Novozym 435: Enhanced activity and operational stability. Ultrason. Sonochem. 2013, 20, 1155-1160. [CrossRef] [PubMed]

51. Graebin, N.G.; Martins, A.B.; Lorenzoni, A.S.G.; Garcia-Galan, C.; Fernandez-Lafuente, R.; Ayub, M.A.Z.; Rodrigues, R.C. Immobilization of lipase B from Candida antarctica on porous styrene-divinylbenzene beads improves butyl acetate synthesis. Biotechnol. Prog. 2012, 28, 406-412. [CrossRef] [PubMed]

52. Paludo, N.; Alves, J.S.; Altmann, C.; Ayub, M.A.Z.; Fernandez-Lafuente, R.; Rodrigues, R.C. The combined use of ultrasound and molecular sieves improves the synthesis of ethyl butyrate catalyzed by immobilized Thermomyces lanuginosus lipase. Ultrason. Sonochem. 2015, 22, 89-94. [CrossRef] [PubMed]

53. Duan, Y.; Zongliang, D.; Yao, Y.; Ruixia, L.; Dacheng, W. Effect of molecular sieves on lipase-catalyzed esterification of rutin with stearic acid. J. Agric. Food Chem. 2006, 54, 6219-6225. [CrossRef] [PubMed]

54. Giacometti, J.; Giacometti, F.; Milin, Č.; Vasić-Rački, D. Kinetic characterisation of enzymatic esterification in a solvent system: Adsorptive control of water with molecular sieves. J. Mol. Catal. B Enzym. 2001, 11, 921-928. [CrossRef]

55. Friedrich, J.L.R.; Pena, F.P.; Garcia-Galan, C.; Fernandez-Lafuente, R.; Ayub, M.A.Z.; Rodrigues, R.C. Effect of immobilization protocol on optimal conditions of ethyl butyrate synthesis catalyzed by lipase B from Candida antarctica. J. Chem. Technol. Biotechnol. 2013, 88, 1089-1095. [CrossRef]

56. Fernandez-Lorente, G.; Palomo, J.M.; Cocca, J.; Mateo, C.; Moro, P.; Terreni, M.; Fernandez-Lafuente, R.; Guisan, J.M. Regio-selective deprotection of peracetylated sugars via lipase hydrolysis. Tetrahedron 2003, 59, 5705-5711. [CrossRef] 
57. Fernandez-Lafuente, R. Lipase from Thermomyces lanuginosus: Uses and prospects as an industrial biocatalyst. J. Mol. Catal. B Enzym. 2010, 62, 197-212. [CrossRef]

58. Adlercreutz, P. Immobilisation and application of lipases in organic media. Chem. Soc. Rev. 2013, 42, 6406-6436. [CrossRef] [PubMed]

59. Bernal, C.; Illanes, A.; Wilson, L. Heterofunctional hydrophilic-hydrophobic porous silica as support for multipoint covalent immobilization of lipases: Application to lactulose palmitate synthesis. Langmuir 2014, 30, 3557-3566. [CrossRef] [PubMed]

60. Lima, L.N.; Oliveira, G.C.; Rojas, M.J.; Castro, H.F.; Da Rós, P.C.M.; Mendes, A.A.; Giordano, R.L.C.; Tardioli, P.W. Immobilization of Pseudomonas fluorescens lipase on hydrophobic supports and application in biodiesel synthesis by transesterification of vegetable oils in solvent-free systems. J. Ind. Microbiol. Biotechnol. 2015, 42, 523-535. [CrossRef] [PubMed]

61. Blanco, R.M.; Terreros, P.; Fernández-Pérez, M.; Otero, C.; Díaz-González, G. Functionalization of mesoporous silica for lipase immobilization: Characterization of the support and the catalysts. J. Mol. Catal. B Enzym. 2004, 30, 83-93. [CrossRef]

62. Séverac, E.; Galy, O.; Turon, F.; Pantel, C.A.; Condoret, J.-S.; Monsan, P.; Marty, A. Selection of CalB immobilization method to be used in continuous oil transesterification: Analysis of the economical impact. Enzym. Microb. Technol. 2011, 48, 61-70. [CrossRef] [PubMed]

63. Do Neta, N.A.S.; dos Santos, J.C.S.; de Sancho, S.O.; Rodrigues, S.; Gonçalves, L.R.B.; Rodrigues, L.R.; Teixeira, J.A. Enzymatic synthesis of sugar esters and their potential as surface-active stabilizers of coconut milk emulsions. Food Hydrocoll. 2012, 27, 324-331. [CrossRef]

64. Walsh, M.K.; Bombyk, R.A.; Wagh, A.; Bingham, A.; Berreau, L.M. Synthesis of lactose monolaurate as influenced by various lipases and solvents. J. Mol. Catal. B Enzym. 2009, 60, 171-177. [CrossRef]

65. Zaidan, U.H.; Abdul Rahman, M.B.; Othman, S.S.; Basri, M.; Abdulmalek, E.; Abdul Rahman, R.N.Z.R.; Salleh, A.B. Biocatalytic production of lactose ester catalysed by mica-based immobilised lipase. Food Chem. 2012, 131, 199-205. [CrossRef]

66. Rueda, N.; Santos, J.C.S.; Torres, R.; Ortiz, C.; Barbosa, O.; Fernandez-Lafuente, R. Improved performance of lipases immobilized on heterofunctional octyl-glyoxyl agarose beads. RSC Adv. 2015, 5, 11212-11222. [CrossRef]

67. Hirata, D.B.; Albuquerque, T.L.; Rueda, N.; Virgen-Ortíz, J.J.; Tacias-Pascacio, V.G.; Fernandez-Lafuente, R. Evaluation of different immobilized lipases in transesterification reactions using tributyrin: Advantages of the heterofunctional octyl agarose beads. J. Mol. Catal. B Enzym. 2016, 133, 117-123. [CrossRef]

68. Virgen-Ortíz, J.J.; Tacias-Pascacio, V.G.; Hirata, D.B.; Torrestiana-Sanchez, B.; Rosales-Quintero, A.; Fernandez-Lafuente, R. Relevance of substrates and products on the desorption of lipases physically adsorbed on hydrophobic supports. Enzym. Microb. Technol. 2017, 96, 30-35. [CrossRef] [PubMed]

69. Hirata, D.B.; Albuquerque, T.L.; Rueda, N.; Sánchez-Montero, J.M.; Garcia-Verdugo, E.; Porcar, R.; Fernandez-Lafuente, R. Advantages of Heterofunctional Octyl Supports: Production of 1,2-Dibutyrin by Specific and Selective Hydrolysis of Tributyrin Catalyzed by Immobilized Lipases. ChemistrySelect 2016, 1, 3259-3270. [CrossRef]

70. Tani, K.; Suzuki, Y. Influence of titania matrix on retention behaviour in reversed-phase liquid chromatography. J. Chromatogr. A 1996, 722, 129-134. [CrossRef]

71. De Paula, A.V.; de Souza Barboza, J.C.; de Castro, H.F. Estudo da influência do solvente, carboidrato e ácido graxo na síntese enzimática de ésteres de açúcares. Quim. Nova 2005, 28, 792-796. [CrossRef]

Sample Availability: Not available. 